\title{
CAN BOARD OF DIRECTORS DIVERSITY AND MONITORING INTENSITY IMPROVE BANK PROFITABILITY?
}

\author{
Septian Yudha Kusuma ${ }^{1 *}$, Sudarman ${ }^{2}$, Vita Arumsari ${ }^{1}$ \\ ${ }^{1} J u r u s a n$ Akuntansi, Politeknik Negeri Semarang, Indonesia \\ ${ }^{2}$ Program Studi Akuntansi, Institut Teknologi dan Bisnis Semarang, Indonesia \\ *Email corresponding author: septian.yudhakusuma@polines.ac.id
}

Received 23/12/2020 Revised 27/01/2021 Published 31/01/2021

\begin{abstract}
This study aims to analyze the board of directors' diversity and monitoring intensity on bank profitability. Board of directors' diversity is measured by a composite index of gender, age, education, citizenship, and independence of the board of directors. Meanwhile, monitoring intensity is measured by the composition of audit quality, the number of meetings, and the committee's number. The objects are banks listed in the Indonesia Stock Exchange period of 2015-2017 with a panel data regression. Selected samples were 40 banks and 120 observations. The results showed that board of directors' diversity had a significant negative on profitability. This result provokes a gap in the previous research and doesn't support resource dependence theory. The board of directors must respond quickly to market needs; however, the board of directors' diversity seems to hinder quality business decisions to increase bank profitability. While monitoring intensity is positively significant to profitability, so this result can support agency theory. Monitoring by diverse boards of directors seems to reduce agency costs, thereby increasing bank profitability effectively. Some practical and implications will be discussed in this study.
\end{abstract}

Key Words: Board of Directors Diversity, Monitoring Intensity, Bank Profitability, Resource Dependence Theory, Agency Theory

\section{INTRODUCTION}

Research about the relationship between boards of directors and profitability is usually based on two theories. As the dominant theory, agency theory states that the board's main activity is supervising management on behalf of shareholders, and effectivity can improve firm performance by reducing agency costs (Hillman and Dalziel, 2003). These researchers have examined the relationship between proxies of board incentives under supervision (e.g., board dependency or stock compensation) and financial performance that has mixed results. Vermoesen et al. (2020) examine cash bonuses paid to directors on firm performance. The result is that directors' bonuses are positively correlated with financial performance, so based on agency theory, these findings can align directors' and shareholders' interests. Different results from Chapple and Humphrey (2014) state that diversity on the board is not related to performance besides that there is a weak negative correlation between having multiple female boards on performance.

While the agency model has dominated corporate governance research in general, and boards of directors in particular, evaluating board members' diversity requires one to take a plural approach, including not only the different board theories, such as resource dependence theory (Fernández-Temprano and Tejerina-Gaite 2020). The theory of resource dependence with basic capital as the main concern. It consists of human capital (experience, expertise, reputation) and relational capital (the network of other companies and external possibilities). Resource dependency theory examines how a board's capital leads to its provision of resources (Hillman and Dalziel, 2003). Empirical studies in resource dependency theory have shown a relationship between board capacity and profitability (Pfeffer, 1972; Kılıç and Kuzey, 2016). Kılıç and Kuzey (2016) use female directors as describing board characteristics, and the result is the diversity of women's boards have a positive impact on financial performance; according to the resource 


\section{PERFORMANCE}

Jurnal Personalia, Financial, Operasional,

Marketing dau Sistem Informasi

Performance. Volume 28 Nomor 1 Tahun 2021, 26-40

dependence theory, female directors have the potential impact on increasing financial performance with different views in the discussion, positive view of shareholders, building positive firm image, and maintain a competitive advantage. Dewi and Dewi (2016) Reinforced show that gender and educational background diversity on the board positively affect firm value.

Indonesia has the same system as countries in Europe, a two-tier board system, where the company has two boards, namely a board of directors that carries out company operations and a board of commissioners that examines the board of directors (Pudjiastuti and Mardiyah, 2007). The board of directors is the most responsible party for the organization's performance, where one of the benchmarks is financial performance.

Board diversity has developed to be a concern and issue in Good Corporate Governance (GCG) in the last decade, in another word, the optimal board composition is needed to produce an optimal GCG (Fidanoski et al., 2014:82). The greater the diversity within board members can cause many conflicts but can provide a variety of alternative solutions compared to homogeneous board members; hence board of directors' diversity can provide unique characteristics for companies that can generate added value (Astuti, 2017).

Board effectiveness requires cultural, experiences, and gender diversity, known as demographic diversity, to guide and contribute to organizational learning and improve management strategic decision making (Ben-Amar et al., 2013). Previous research distinguished between demographic diversity and structural diversity (Ben-Amar et al., 2013; Ararat et al., 2015). The impact of demographic diversity is generally associated with service tasks, while structural diversity is measured by board independence, which is linked to controlling tasks (Ararat et al., 2015).

According to Forbes and Milliken (1999), the board's characteristics consist of demographics and knowledge/skills (cognitive). Board diversity can be a unique characteristic but impactful on increasing conflict, increasing the cognitive conflict for decision making to the company. Increased cognitive conflict can result in effective decision-making, ultimately impacting firm performance (Forbes and Milliken, 1999). For example, van den Oever and Beerens (2020) investigate how board gender diversity impacts task-related conflict and how task-related conflict, in turn, impacts organizational performance, and their findings find evidence for a partial mediating role of taskrelated conflict in the organizational performance relationship of board gender diversity. Monitoring carried out by the board of directors can cause agency costs due to separation of ownership and control to improve company performance (Fama, 1980; Zahra and Pearce, 1989). Further, this is also effective when the company has bigger control than the partner as the owner gets bigger (Nguyen, Vu, and Doan 2020). Khan et al. (2020) study confirms the literature that the agency's cost and company performance are negatively connected to the listed Chinese companies.

The research results on demographic, cognitive and structural diversity on profitability have mixed results (Mahadeo et al., 2012; Ararat et al., 2015; Herdhayinta et al., 2017; RegueraAlvarado et al., 2017; Kusuma et al., 2018). The inconsistency of the results caused by different locations, methodology, and variables (Hermalin and Weisback, 2003; Carter et al., 2010). Studies on the demographic diversity effect on firm performance in emerging markets are rarely studied and not statistically significant or only focus on a single dimension of diversity such as gender or race (Ararat et al., 2015). This study will integrate demographic, structural and cognitive diversity in the board of directors diversity to enrich previous research (Chapple and Humphrey, 2014; Fidanoski et al., 2014; Ramadhani and Adhariani, 2015; Galbreath, 2016; Kılıç and Kuzey, 2016; Gordini and Rancati, 2017; Reguera-Alvarado et al., 2017). 


\section{LITERATURE REVIEW AND HYPOTHESIS DEVELOPMENT}

\section{Agency Theory}

The board supervision function, described as a "control" (Zahra and Pearce, 1989; Pearce and Zahra, 1992; Johnson et al., 1996), has drawn attention to corporate governance researchers from several disciplines (law, finance, sociology, and strategic management) for several years (Hillman and Dalziel, 2003) for example Khan et al. (2020). The basis for the theory of board supervision function comes from agency theory, which describes the potential for conflicts that arise due to the separation of ownership and control in organizations (Berle and Means, 1932; Fama and Jensen, 1983). Theorists concluded that the primary function of the board is to monitor the actions of the "agent" (management) to protect the interest of the owner's "principal" (Jensen and Meckling, 1976; Eisenhardt, 1989).

Board monitoring is important because of the potential costs incurred when management pursues its interests at shareholders' expense (Hillman and Dalziel, 2003). When ownership and control are separated like most modern companies today, managers can pursue their self-interest at the expense of profit maximization, thus creating "agency" costs (Berle and Means, 1932). Monitoring by the board of directors can reduce agency costs inherent in separating ownership and control and can improve firm performance (Fama, 1980; Zahra and Pearce, 1989). Ararat et al. (2015) stated that diversity could lead to better monitoring by preventing groupthink and triggering critical investigations to produce decisions that can improve financial performance.

\section{Resource Dependency Theory}

The second important board function is providing resources. This function refers directly to the board's ability to bring resources to the company, resources of whatever may be considered a particular firm's strength or weakness (Wernerfelt, 1984:172). The theoretical thinking of this function is based on Pfeffer and Salancik (1978) regarding resource dependence. Pfeffer and Salancik (1978:163) stated that "when an organization appoints an individual to a board, the organization expects that the individual will support the organization, focus his attention on organizational problems, vary its ways to convey it to others, and will trying to support the organization ". Some of the benefits that can be provided by the board: (1) advice, (2) legitimacy, (3) information communication channels between external organizations and the company, and (4) access of preference commitments or support from important elements outside the company (Hillman and Dalziel, 2003).

The resource dependency logic suggests that board resources are directly related to firm performance (Hillman and Dalziel, 2003). Resources help reduce dependency between organizations and external contingencies (Pfeffer and Salancik, 1978), reduce the uncertainty of the firm (Pfeffer 1972), reduce transaction costs (Williamson 1984), and ultimately help the survival of the firm (Singh et al., 1986).

The terminology used in board-related resource dependency theory is human capital (Hillman and Dalziel, 2003). Resource dependency theory researchers discuss the expertise, experiences, knowledge, reputation, and skills of the board of directors (Becker 1993; Coleman 1988). They also discuss the role of board bonding for external organizations ( $\mathrm{H}$. White 1961; $\mathrm{H}$. C. White 1963; Jacobs 1961), who study relational capital in social bonds. Relational capital, or so-called social capital, explicitly refers to "the actual and potential amount of resources embedded, available, and derived from the network of relationships of individuals or social units" (Nahapiet and Ghoshal, 1998). Thus, the term board capital (including human and relational capital) is a useful way of understanding the provision of board resources to firms, linked to firm performance (Hillman and Dalziel, 2003). 
Performance. Volume 28 Nomor 1 Tahun 2021, 26-40

Relationship Between Board of Directors Diversity and Bank Profitability

According to Fidanoski et al. (2014:82), board diversity has become a concern of the crucial issue of Good Corporate Governance (GCG) in the last decade, or it can be said that the optimal board composition can produce optimal GCG. Meanwhile, according to Astuti (2017), greater diversity in board members causes many conflicts, but on the other hand, conflicts that arise can provide various alternative solutions compared to homogeneous board members, so that diversity on the board of directors can provide unique characteristics for companies that can create value-added.

The logic of resource dependence implies that board resources are directly linked to company efficiency (Hillman and Dalziel 2003). Tools help minimize organizational dependence and external contingencies (Pfeffer and Salancik 1978), reduce business instability (Pfeffer 1972), decrease transaction costs (Williamson 1984), and eventually help the company's survival (Singh et al., 1986).

Board effectiveness requires cultural, experiential, and gender diversity, known as demographic diversity, to guide and contribute to organizational learning and improve management strategic decision making (Ben-Amar et al., 2013). Previous research distinguished between demographic diversity and structural diversity (Ben-Amar et al., 2013; Ararat et al., 2015). The impact of demographic diversity is generally related to service tasks, while structural diversity is measured by board independence associated with control tasks (Ararat et al., 2015).

According to Forbes and Milliken (1999), the board's characteristics consist of demographics and knowledge/skills (cognitive). Board diversity can be a unique characteristic, but the impact on increasing conflict, thus increasing cognitive conflict for the company. Increased cognitive conflict can result in effective decision-making, ultimately impacting firm performance (Forbes and Milliken, 1999). Cognitive diversity can improve cognitive conflict between boards so that it can stimulate "investigative and critical interaction processes" (Amason, 1996:104) and will increase the performance of board control (Forbes and Milliken, 1999:494). The empirical research results also show that diversity of opinions and conflicts can contribute to strategic decision-making quality (Schweiger et al., 1986).

Previous research that discussed demographic, cognitive and structural diversity on the financial performance obtained different results. Fernandes et al. (2017) found that age and gender diversity improved banks' performance during the crisis, so diversity is significant. Talavera et al. (2018) found in Chinese banks that age diversity has a significant negative effect on bank profitability, and also, heterogeneity of directors' perceptions about risk, prudence, and wealth harms bank profitability. Research that has been conducted by Kusuma et al. (2018) found that gender diversity does not affect bank performance. Although significant internationalization of the board harms bank results, foreign directors' involvement tends to be less harmful during the crisis in the Eurozone and diversity-friendly countries (Arnaboldi et al. 2020). Gafoor et al. (2018) also see positive and meaningful ties between the board's independence and bank performance.

This research tries to analyze several aspects of the board of directors' diversity, namely gender, age, foreign boards, independence board, and education, and then combine it into a single board diversity index according to Ararat et al. (2015). Then the hypothesis is as follows: $\mathrm{H}_{1}$ : Board of directors' diversity influences bank profitability.

\section{Relationship Monitoring Intensity and Bank Profitability}

Board of directors' oversight will reduce the agency's costs inherent in dividing ownership and management and boost organization efficiency (Fama, 1980; Zahra and Pearce, 1989). Effective monitoring is expected to weaken agency conflict within the company (Ararat et al., 2010), thereby increasing profitability. We use the board of directors' number of meetings, audit quality, and a board committee to describe monitoring intensity-based from Ararat et al. (2015). The results of research by Lai et al. (2017) revealed that audit committees with female directors 
Performance. Volume 28 Nomor 1 Tahun 2021, 26-40

(members) are more likely to expect higher audit quality, but on the other hand, Erin et al. (2018) in Nigeria found that audit committee has not to effect on bank performance. Phan et al. (2020) show that the firms' financial performance listed on the Hanoi Stock Trading Floor was favorably affected by the audit quality. Gafoor et al. (2018) results find that for bank performance, the number of board meetings and a greater number of financial experts on the board are significant. Simultaneously, the research results of Ararat et al. (2010) found that board diversity has a significant positive effect on monitoring intensity conducted by the board. Then the hypothesis is as follows:

$\mathrm{H}_{2}$ : Monitoring intensity influences bank profitability.

\section{RESEARCH METHODOLOGY}

The population used in this study is conventional banks listed on the Indonesia Stock Exchange from 2015-2017, which present annual reports on each bank's websites. The sampling technique uses total sampling. Data collection obtained 40 conventional banks as units of analysis that met the criteria; hence, the number of observation units in this study was three periods multiplied by 40 observation units, 120 observations.

Table 1. Sample Calculation

\begin{tabular}{clc}
\hline No & \multicolumn{1}{c}{ Description } & Total \\
\hline 1 & Conventional bank population & 43 \\
\hline 2 & $\begin{array}{l}\text { Not listed on the IDX for three } \\
\text { consecutive years (ARTO and BTPS) }\end{array}$ & $(2)$ \\
\hline 3 & $\begin{array}{l}\text { Acquisition and changed bank name } \\
\text { (BEKS) }\end{array}$ & $(1)$ \\
\hline & Total sample & 40 \\
\hline
\end{tabular}

While the variables in this research can be seen in Table 2 .

Table 2. Research Variables

\begin{tabular}{|c|c|c|c|}
\hline No & Variable & Operational Definition & Information \\
\hline 1 & $\begin{array}{l}\text { Bank } \\
\text { Profitability } \\
\text { (Independent) }\end{array}$ & $\begin{array}{l}\text { Profitability is the bank's ability } \\
\text { to generate profits (Swandayani } \\
\text { and Kusumaningtias, 2012). }\end{array}$ & $\begin{array}{l}\text { ROA }=\frac{\text { Profit before Tax }}{\text { Total Average of the Asset }} \\
\text { (Horne and Wachowicz 2008) }\end{array}$ \\
\hline 2 & $\begin{array}{l}\text { Board Diversity } \\
\text { (Dependent) }\end{array}$ & $\begin{array}{l}\text { The board diversity is a } \\
\text { heterogeneous board in terms of } \\
\text { gender, age, race, education, } \\
\text { experience, lifestyle, culture, } \\
\text { religion, and other aspects that } \\
\text { can create uniqueness (Mishra } \\
\text { and Jhunjhunwala, 2013). }\end{array}$ & $\begin{array}{l}\text { 1. Gender diversity consists of two } \\
\text { categories, female and male. } \\
\text { 2. Age dispersion is measured with five } \\
\text { categories: } 1=25-35 ; 2=36-45 ; 3=46- \\
55 ; 4=56-65 \text { and } 5=\text { more than } 65 \\
\text { years. } \\
\text { 3. The diversity of the foreign board of } \\
\text { directors consists of two categories: } \\
\text { board of directors with foreign } \\
\text { nationality and Indonesian nationality. } \\
\text { 4. Independence diversity consists of two } \\
\text { categories: the independent board of } \\
\text { directors and the non-independent } \\
\text { board of directors. } \\
\text { There are five categories of education } \\
\text { diversity, they are elementary school } \\
\text { and junior high school, senior high } \\
\text { school, diploma/bachelor, master, and } \\
\text { doctoral (Ararat et al., 2015) }\end{array}$ \\
\hline
\end{tabular}


Performance. Volume 28 Nomor 1 Tahun 2021, 26-40

\begin{tabular}{|c|c|c|c|}
\hline 4 & $\begin{array}{l}\text { Monitoring } \\
\text { Intensity } \\
\text { (Dependent) }\end{array}$ & $\begin{array}{l}\text { Board monitoring intensity is the } \\
\text { board's role as supervisor to } \\
\text { ensure managers pursue } \\
\text { stakeholders' interests (Lahlou, } \\
\text { 2018). }\end{array}$ & $\begin{array}{l}\text { 1. Number of integrated meetings } \\
\text { between commissioners and directors. } \\
\text { Number of meeting } 3-12=1 ; 13-30=2 \\
\text { and }>30=3 \text {. } \\
\text { 2. The number of board committees is a } \\
\text { few formed board committees. } \\
\text { Number of committee } 0-1=1 \text {, number } \\
\text { of committee } 2=2 \text { and number of } \\
\text { committee }>3=3 \text {. } \\
\text { 3. Auditor quality is measured by } \\
\text { categorized into three categories: } \\
\text { Auditor Big-4 = 3, international auditor } \\
=2, \text { and local auditor = } 1 \text { (Ararat et al., } \\
\text { 2015) }\end{array}$ \\
\hline 5 & $\begin{array}{l}\text { Firm } \\
\text { (Control) }\end{array}$ & $\begin{array}{l}\text { Darmawati (2015) stated that } \\
\text { the companies' size calculations } \\
\text { aim to assess the companies' } \\
\text { value. }\end{array}$ & $\begin{array}{l}\text { Firm Size = Ln Total Aset } \\
\text { (Kılıç and Kuzey, 2016) }\end{array}$ \\
\hline 6 & $\begin{array}{l}\text { Leverage } \\
\text { (Control) }\end{array}$ & $\begin{array}{l}\text { Leverage is the companies' } \\
\text { ability in fulfilling the long-term } \\
\text { responsibility and short-term } \\
\text { responsibility when the } \\
\text { companies are liquidated } \\
\text { (Darmawati, 2015) }\end{array}$ & $\begin{array}{l}\text { Leverage }=\frac{\text { Total Book Value of Debt }}{\text { Total Asset Book Value }} \\
\text { (Abdullah, 2004) }\end{array}$ \\
\hline
\end{tabular}

Each category in the board diversity variable is measured using the Blau Index (Blau, 1977):

$$
1-\sum_{\mathrm{i}=1}^{\mathrm{k}} \mathrm{P}_{\mathrm{i}}^{2}
$$

where,

$\mathrm{P}_{\mathrm{i}}=$ proportion of board member in the $i$ category from attributes

$\mathrm{k}=$ number of attributes' categories

Standardizing the Blau index for each of the five board diversity attributes is done by dividing each attribute by the theoretical maximum value $((k-1) / k)$. To measure the board of directors' diversity, this research tries to build a composite index by adding up all the standardized values of the Blau Index for all the diverse attributes of the board (Agresti and Agresti, 1978). The monitoring intensity variable's measurement uses a scale of comparison between the value obtained by each company within a year divided by its maximum value; hence, a single index of monitoring intensity is obtained. Apart from variables related to board diversity and monitoring intensity, two control variables were also included in this study. According to Reguera-Alvarado et al. (2017), this study controls the firm size in the LN_ASET variable. The second is leverage (LEV), according to Ararat et al. (2015).

The research method used is a quantitative descriptive analysis method of all the variables studied. This study also uses regression analysis to determine the effect of the independent variable toward the dependent variables with the following equation:

$$
R O A=\alpha+\beta_{1} K D+\beta_{2} I M+\beta_{3} L N \_A S E T+\beta_{4} L E V+e_{2}
$$

Definition:

ROA : Return on Assets (Bank Profitability)

KD : Board of Directors Diversity

IM : Monitoring Intensity 
LN_ASET : Firm Size

LEV : Leverage

$\alpha \quad$ : Constant

B : Coefisien

e $\quad$ : error of term

Further, regression analysis with the above equation is performed by first carrying out a classic assumption test consisting of normality, multicollinearity and heteroscedasticity tests. Furthermore, testing the model's accuracy consisting of the model significance test (statistical test $\mathrm{F}$ ), test the coefficient of determination $\mathrm{R}^{2}$, and hypothesis testing. We use SPSS 26 version to analyze data. Based on equation (2), the research framework can be seen as follows:

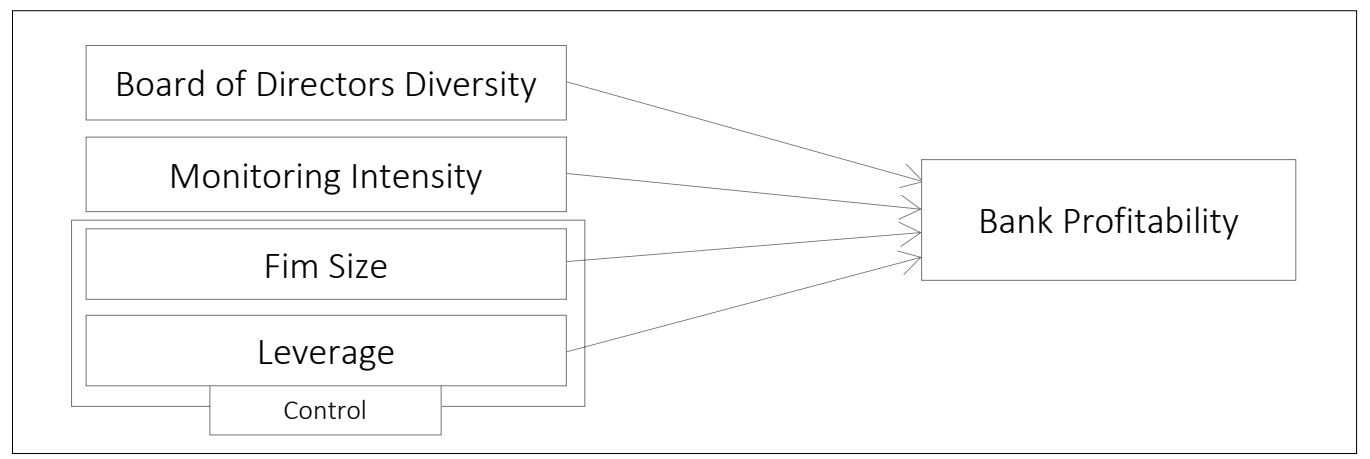

Figure 1. Research Framework

\section{RESULT AND DISCUSSION}

\section{Descriptive Statistics}

Descriptive statistics presented in this research is the minimum value, maximal, average, and standard deviation values are presented in Table 3.

Table 3. Descriptive Statistics

\begin{tabular}{lcrrrr}
\hline & N & \multicolumn{1}{c}{ Min } & \multicolumn{1}{c}{ Max } & \multicolumn{1}{c}{ Mean } & \multicolumn{1}{c}{ Std. Deviation } \\
\hline KD & 120 & 0,40 & 3,57 & 1,9901 & 0,82984 \\
\hline IM & 120 & 0,56 & 1,00 & 0,7713 & 0,09801 \\
\hline ROA & 120 & $-0,11$ & 0,04 & 0,0099 & 0,02171 \\
\hline LN_ASET & 120 & 28,31 & 34,61 & 31,0549 & 1,78322 \\
\hline LEV & 120 & 0,61 & 0,94 & 0,8443 & 0,04920 \\
\hline Valid N (listwise) & 120 & & & & \\
\hline
\end{tabular}

Sources: Processed Data

The highest variable KD of 3,57 was BKSW in 2015, and the lowest 0,4 was BACA in 2015 and BJTM in 2015-2016, the average value was 1,9901 and standard deviation 0,82984. The highest variable IM as much as 1 was BBRI in 2015, BBTN in 2016-2017, as well as MEGA in 2016-2017 and the lowest 0,56, was INPC in 2016, BBNP in 2017 and BBMD in 2015-2017, the average value was 0,7713 , and the standard deviation was 0,09801 . The highest variable value of ROA 0,04 was BBRI in 2015, and the lowest 0,11 was BSWD in 2016 with an average value of 0,0099 and standard deviation of 0,02171 .

The highest variable value of LN_ASET 34,61 was BBRI in 2017, and the lowest 28,31 was BGTB in 2015, with an average value was 31, 0549 and a standard deviation of 1,78322. The highest variable value of LEV 0,94 was BBPK in 2015, and the lowest 0,61 was BINA in 2017 with an average value of 0,8443 and standard deviation of 0,04920 . 


\section{Classic Assumptions Test}

In this study, the normality test used the Skewness test model. The normality test in Table 4 showed that the Skewness value was $-3,335$, so the Zskew value obtained was $-14,91$ below 1,96 that it can be said the data has been normally distributed.

Table 4. Normality Tes

\begin{tabular}{lccc}
\hline & $\mathrm{N}$ & \multicolumn{2}{c}{ Skewness } \\
\cline { 2 - 4 } & Statistic & Statistic & Std. Error \\
\hline Unstandardized Residual & 120 & $-3,335$ & 0,221 \\
\hline Valid N (listwise) & 120 & & \\
\hline
\end{tabular}

Sources: Processed Data

To determine whether multicollinearity can be seen from the tolerance value and VIF value. If the tolerance value is $>0.05$ and the VIF value is $<10$, then the model free from multicollinearity. The multicollinearity test in Table 5 depicts that all variables have tolerance values are $>0.05$, and VIF values are $<10$, then it is free of multicollinearity.

Table 5. Multicollinearity Test

\begin{tabular}{|c|c|c|c|}
\hline & \multirow[t]{2}{*}{ Model } & \multicolumn{2}{|c|}{ Collinearity Statistics } \\
\hline & & Tolerance & VIF \\
\hline \multirow[t]{5}{*}{1} & (Constant) & & \\
\hline & KD & 0,953 & 1,049 \\
\hline & $\mathrm{IM}$ & 0,959 & 1,042 \\
\hline & LN_ASET & 0,904 & 1,107 \\
\hline & LEV & 0,972 & 1,029 \\
\hline \multicolumn{4}{|c|}{ a. Dependent Variable: ROA } \\
\hline
\end{tabular}

The white test was used to test for heteroscedasticity. The heteroscedasticity test in Table 6 in significance level of 0,05 shows that it is free of heteroscedasticity.

Table 6. Heteroscedasticity Test

\begin{tabular}{lll}
\hline \multicolumn{1}{c}{ Chi-Square } & df & Sig. \\
\hline 14,854 & 14 & 0,388 \\
\hline
\end{tabular}

Source: Processed Data

\section{Hypothesis Testing}

$F$ test was exercised to test the accuracy of the regression model. From the calculation result, it obtained $F$ value $=10,5707(p=0,0000)$, then it can be concluded that the model is fit at $5 \%$ degree of confidence. Determinant coefficient $\left(\operatorname{Adj} R^{2}\right)$ means that the model's ability to explain the profitability variable was $24,3 \%$, and $75,7 \%$ was explained by the other variables from the research model. Based on Table 7, the multiple linear regression equation as follows:

$$
\text { ROA }=-0,1040+-0,0055 K D+0,0395 I M+0053 L N \_A S E T+-0,0824 L E V+e_{z} .
$$

Table 7. Hypothesis Test

\begin{tabular}{lcccc}
\multicolumn{1}{c}{ Variable } & Coefficient & T & Sig. t & Conclusion \\
\hline Constant & $-0,1040$ & & & \\
\hline KD & $-0,0055$ & $-2,5618$ & 0,0117 & Significant \\
\hline IM & 0,0395 & 2,1909 & 0,0305 & Significant \\
\hline LN_ASET & 0,0053 & $-5,1695$ & 0,0000 & Significant \\
\hline LEV & $-0,0824$ & $-2,3085$ & 0,0228 & Significant \\
\hline$R=0,5185 R^{2}=0,2688$ Adj $R^{2}=0,243$ & & & \\
$F=10,5707 p=0,0000$ & & & & \\
\hline
\end{tabular}

Sources: Processed Data 


\section{PERFORMANCE}

Jurnal Personalia, Financial, Operasional,

Marketing dau Sistern Informasi

Performance. Volume 28 Nomor 1 Tahun 2021, 26-40

Further, the hypothesis tests are done by using a multiple regression model. The hypothesis test was performed by using a t-test. t-test was done by observing the significance level of $5 \%$ to identify whether or not there is significance influence among tested variables (Ghozali 2016). Table 6 show that all hypothesis test can be accepted. It can be concluded as follows: 1) Board of directors diversity $(K D) t_{\text {value }}-2,5618<t_{\text {table }}=-1,98081$ or significance $=0,0117<0,05$ and coefficient value $-0,0055$ which means there is a significant negative effect between board of directors diversity toward bank profitability, so hypothesis 1 accepted. 2) Monitoring intensity (IM) $t_{\text {value }} 2,1909>t_{\text {table }}=1,98081$ or significance $=0,0305<0,05$ and coefficient value 0,0395 which means there is a significant positive effect between monitoring intensity toward bank profitability, so hypothesis 2 accepted. 3) Firm size (LN_ASET) as control variable $t_{\text {value }}-5,1695<t_{\text {table }}=-1,98081$ or significance $=0,0000<0,05$ and coefficient value 0,0053 which means there is a significant positive effect between firm size toward bank profitability. 4) Leverage (LEV) as control variable $t_{\text {value }}-2,3085<t_{\text {table }}=-1,98081$ or significance $=0,0228<0,05$ and coefficient value $-0,0824$ which means there is a significant negative effect between leverage toward bank profitability.

\section{DISCUSSION}

\section{Relationship Between Board of Directors Diversity and Bank Profitability}

The first hypothesis test showed that the board diversity has a significant negative effect on profitability by identifying the significance level below $5 \%(p=0,0117)$. The logic of resource dependence is essentially the capital/resource attached to the board of directors in running the company. This study's findings prove that the board of directors has not used all its capabilities to improve bank performance. These results showed that board diversification tends to lower the banks' profitability compared with the research done by Ararat et al. (2015). Previous research that used the same variables has not many things to do; hence this result can be a gap of the previous studies. It can be comprehended that the researches' diversity in a team can lead to a loss process (Steiner, 1972), which comes from conflict and communication problems (Miller and Triana, 2009).

These results also reject the statement of Forbes and Milliken (1999), which stated that the increasing cognitive conflict within the board of directors could cause effective decision making, which affects the companies' performance. The board of directors' diversity may require a process to achieve good results; even diversity is also required a good decision-making process. However, the fast decision-making process takes time, especially if there is a rotation of directors every year. The variety of board decision might have better quality in the end but failed to balance the negative effect from the decision-making process which tend to be slow when the market demand fast response (Hambrick et al., 1996). This paper result aligns with Talavera et al. (2018) research in China also finds the contrary finding. This is about the communication barrier that happened among board members with different age gaps, although Darmadi (2011) mentioned that young members' presence tends to boost the financial performance. Talavera et al. (2018) further mentioned that it depends on the diversity of personal values as it should be noticed that China's cultural value is different; hence they find that less age-diversity will take the company in a similar direction that board of directions goes into. On the contrary, according to Arioglu (2020), it is a different case with Turkey, although they do not value diversity as it will lead to conflict, the decision-making lies in the superiors, as they have a paternal culture that leads the older to make the decisions. Indonesia has a better culture than Turkey in terms of diversity, which should be an added value for companies, especially banking in Indonesia.

\section{Relationship Monitoring Intensity and Bank Profitability}

The results of testing the second hypothesis indicate that the intensity of monitoring has a significant positive effect on profitability, as is seen from the significance level, which was below $5 \%(p=0.0305)$. The result support previous research conducted by Ararat et al. (2010). Hermalin 


\section{PERFORMANCE}

Jurnal Personalia, Financial, Operasional,

Marketing dau Sistem Informasi

Performance. Volume 28 Nomor 1 Tahun 2021, 26-40

and Weisback (2003) suggest that stronger monitoring can improve firm performance by reducing agency costs. It is believed that the stronger the agency conflict, the higher the connection between the intensity of board monitoring and firm performance (Ebenezer, 2017). The monitoring role played by the board of directors is an important corporate governance control mechanism (Campbell and Mínguez-Vera, 2008). Hence a good corporate governance mechanism will improve stakeholders' value-added. It improves the financial performance (Mahrani and Soewarno 2018). Monitoring by the board of directors can reduce agency costs inherent in separating ownership and control and can improve firm performance (Fama, 1980; Zahra and Pearce, 1989). So, this result can support agency theory.

The control variables tested showed consistent results with previous researches (Ararat et al., 2015; Ramadhani and Adhariani, 2015; Gordini and Rancati, 2017). Firm size has a significant positive effect on profitability seen from a significance level below $5 \%(p=0.0000)$, while leverage has a significant negative effect on profitability seen from a significance level below $5 \%$ ( $p=$ 0.0228).

\section{CONCLUSION}

The purpose of this study was to examine the effect of board diversity and monitoring intensity on profitability. The research object is a conventional bank listed on the IDX for the 20152017 period using total sampling. Hence 40 banks and 120 observations were obtained. Data sources are obtained from the annual reports published on the websites of each bank. The results of data analysis can be concluded as follows: 1) Board of directors' diversity has a significant negative effect on profitability, so the first hypothesis is accepted. Even though the hypothesis is accepted, it has a negative direction, which means that high diversity has implications for decreased profitability, so that it becomes a theoretical gap as well as the results of previous studies (e.g., Ararat et al., 2015), so this result doesn't support resource dependence theory. The board of directors is required to respond quickly to market needs. However, the board of directors' diversity seems to hinder quality business decisions to increase bank profitability. 2) Other results show that monitoring intensity has a significant positive effect on profitability. Therefore, the second hypothesis is accepted, which means that monitoring activities carried out by the board have a positive impact on profitability so that this result can support agency theory. Monitoring by diverse boards of directors seems to reduce agency costs, thereby increasing bank profitability effectively.

The practical implication for banking is that the board of directors' diversity should increase profitability, not only as a "window dressing" or even merely fulfilling the board of directors (Carter et al., 2003). Meanwhile, the intensity of monitoring has been shown to increase profitability. This research is limited to banking objects only. Therefore, it cannot be generalized. The next research can add other objects and increase observation's period to make it more comprehensive. Even though all the hypotheses are accepted, Adj $R^{2}$ is classified as low at only $24.3 \%$, so it is necessary to explore other variables that affect profitability. Because of the gap in the research results between the board of directors' diversity and profitability, future research can also analyze decision-making processes that can affect profitability so that there may be a mediating variable involved (Forbes and Milliken, 1999).

\section{REFERENCE}

Abdullah, Shamsul Nahar. (2004). Board Composition, CEO Duality and Performance among Malaysian Listed Companies. Corporate Governance: The International Journal of Business in Society 4 (4): 47-61. https://doi.org/10.1108/14720700410558871.

Agresti, Alan, and Barbara F. Agresti. (1978). Statistical Analysis of Qualitative Variation. 
Jurnal Personalia, Financial, Operasional,

Marketing dau Sistern Informasi

Performance. Volume 28 Nomor 1 Tahun 2021, 26-40

Sociological Methodology 9: 204-237. https://doi.org/10.1007/978-1-4419-1270-1.

Amason, A C. (1996). Distinguishing the Effects of Functional and Dysfunctional Conflict on Strategic Decision Making: Resolving a Paradox for Top Management Teams. Academy of Management Journal 39 (1): 123-48.

Ararat, Melsa, Mine Aksu, and Ayşe Çetin. (2010). The Impact of Board Diversity on Boards' Monitoring Intensity and Firm Performance: Evidence from the Istanbul Stock Exchange. 133.

Ararat, Melsa, Mine Aksu, and Ayse Tansel Cetin. (2015). How Board Diversity Affects Firm Performance in Emerging Markets: Evidence on Channels in Controlled Firms. Corporate Governance: An International Review 23 (2): 83-103. https://doi.org/10.1111/corg.12103.

Arioglu, Emrah. (2020). Board Age and Value Diversity: Evidence from a Collectivistic and Paternalistic Culture. Borsa Istanbul Review. https://doi.org/10.1016/j.bir.2020.10.004.

Arnaboldi, F., B. Casu, E. Kalotychou, and A. Sarkisyan. (2020). The Performance Effects of Board Heterogeneity: What Works for EU Banks? European Journal of Finance 26 (10): 897-924. https://doi.org/10.1080/1351847X.2018.1479719.

Astuti, Eni Puji. (2017). Pengaruh Diversitas Dewan Direksi Terhadap Nilai Perusahaan Pada Perusahaan Manufaktur Yang Terdaftar Di Bursa Efek Indonesia Periode 2008-2011. KREATIF : Jurnal IImiah Prodi Manajemen Universitas Pamulang 4 (2): 159-79.

Becker, Gary S. (1993). Human Capital. The University of Chicago Press. Third. Chicago: The University of Chicago Press. https://doi.org/10.1093/nq/s1-IV.92.83-a.

Ben-Amar, Walid, Claude Francoeur, Taïeb Hafsi, and Réal Labelle. (2013). What Makes Better Boards? A Closer Look at Diversity and Ownership. British Journal of Management 24 (1): 85-101. https://doi.org/10.1111/j.1467-8551.2011.00789.x.

Berle, Adolf A., and Gardiner C. Means. (1932). The Modern Corporation and Private Property. New York: The Macmillan Company.

Blau, P. M. (1977). Inequality and Heterogeneity: A Primitive Theory of Social Structure. New York: Free Press.

Carter, David A., Frank D'Souza, Betty J. Simkins, and W. Gary Simpson. (2010). The Gender and Ethnic Diversity of US Boards and Board Committees and Firm Financial Performance. Corporate Governance: An International Review 18 (5): 396-414. https://doi.org/10.1111/j.1467-8683.2010.00809.x.

Carter, David A, Betty J Simkins, and W Gary Simpson. (2003). Corporate Governance, Board Diversity, and Firm Value. The Financial Review 38: 33-53.

Chapple, Larelle, and Jacquelyn E Humphrey. (2014). Does Board Gender Diversity Have a Financial Impact? Evidence Using Stock Portfolio Performance. Journal of Business Ethics 122 (4): 709-23. https://doi.org/10.1007/s10551-013-1785-0.

Coleman, James S. (1988). "Social Capital in the Creation of Human Capital. The American Journal of Socilogy 94: 1-27. https://www.crcresearch.org/files-crcresearch/File/coleman_88.pdf. 
Jurnal Personalia, Financial, Operasional,

Marketing dau Sistem Informasi

Performance. Volume 28 Nomor 1 Tahun 2021, 26-40

Darmadi, Salim. (2011). Board Diversity and Firm Performance: The Indonesian Evidence. Corporate Ownership and Control 8: 1-38. https://doi.org/10.22495/cocv8i2c4p4.

Darmawati, Deni. (2015). Pengaruh Tanggung Jawab Sosial Perusahaan Terhadap Kinerja Dan Risiko Perbankan Di Indonesia. Finance and Banking Journal 17 (1): 83-97.

Ebenezer, Agyemang Badu. (2017). Board Monitoring Intensity and Firm Performance Nexus : The Moderating Effect of Agency Conflict. Journal of Public Policy and Administration 1 (1): 3543. https://doi.org/10.11648/j.jppa.20170101.14.

Eisenhardt, Kathleen M. (1989). Agency Theory: An Assessment and Review. Academy of Management Review 14 (1): 57-74.

Erin, Olayinka, Osariemen Asiriuwa, Paul Olojede, Opeyemi Ajetunmobi, and Timothy Usman. (2018). Does Risk Governance Impact Bank Performance? Evidence From the Nigerian Banking Sector. Academy of Accounting and Financial Studies Journal 22 (4): 1-14.

Fama, Eugene F. (1980). Agency Problems and the Theory of the Firm. The Journal of Political Economy 88 (2): 288-307. https://doi.org/10.1086/260866.

Fama, Eugene F., and Michael C. Jensen. (1983). Separation of Ownership and Control. Journal of Law \& Economics 26 (2): 301-25.

Fernandes, Caterina, Jorge Farinha, Francisco Vitorino Martins, and Cesario Mateus. (2017). Supervisory Boards, Financial Crisis and Bank Performance. Journal of Banking Regulations 18 (4): 310-37.

Fernández-Temprano, Miguel A., and Fernando Tejerina-Gaite. (2020). Types of Director, Board Diversity and Firm Performance. Corporate Governance 20 (2): 324-42. https://doi.org/10.1108/CG-03-2019-0096.

Fidanoski, Filip, Kiril Simeonovski, and Vesna Mateska. (2014). Corporate Governance in the US and Global Settings The Impact of Board Diversity on Corporate Performance: New Evidence from Southeast Europe. Corporate Governance in the US and Global Settings 17: 81-123. https://doi.org/10.1108/S1569-373220140000017003.

Forbes, Daniel P., and Frances J. Milliken. (1999). Cognition and Corporate Governance: Understanding Boards of Director as Strategic Decision-Making Groups. Academy of Management Review 24 (3): 489-505.

Gafoor, C. P. Abdul, V. Mariappan, and S. Thyagarajan. (2018). Board Characteristics and Bank Performance in India. IIMB Management Review 30 (2): 160-67. https://doi.org/10.1016/j.iimb.2018.01.007.

Galbreath, Jeremy. (2016). Is Board Gender Diversity Linked to Financial Performance? The Mediating Mechanism of CSR. Business and Society 57 (5): 1-27. https://doi.org/10.1177/0007650316647967.

Ghozali, Imam. (2016). Aplikasi Analisis Multivariate Dengan Program IBM SPSS 23. 8th ed. Semarang: Badan Penerbit Universitas Diponegoro.

Gordini, Niccolo, and Elisa Rancati. (2017). Gender Diversity in The Italian Boardroom and Firm 
Jurnal Personalia, Financial, Operasional,

Marketing dau Sistem Informasi

Performance. Volume 28 Nomor 1 Tahun 2021, 26-40

Financial Performance. Management Research Review 40 (1).

Hambrick, Donald C., Theresa Seung Cho, and Ming Jer Chen. (1996). The Influence of Top Management Team Heterogeneity on Firms' Competitive Moves. Administrative Science Quarterly 41 (4): 659-84. https://doi.org/10.2307/2393871.

Herdhayinta, Heyvon, Grahita Chandrarin, Sumiyana, and Anwar Fitrianto. (2017). The Influence of Board Diversity on Financial Performance: An Empirical Study of Asia-Pacific Companies Using Regression Models. International Business Management 11 (1): 88-99. https://doi.org/10.3923/ibm.2017.89.99.

Hermalin, Benjamin E., and Michael S Weisback. (2003). Boards of Directors as an Endogenously Determined Institution : A Survey of the Economic Literature.

Hillman, Amy J., and Thomas Dalziel. (2003). Boards of Directors and Firm Performance: Integrating Agency and Resource Dependence Perspectives. Academy of Management Review 28 (3): 383-96.

Horne, James C. Van, and John M. Wachowicz. (2008). Fundamentals of Financial Management. 13th ed. Harlow, England; New York: Financial Times/Prentice Hall. https://www.pdfdrive.com/fundamentals-of-financial-management-van-horne-13thedition-e28727448.html.

Jacobs, Jane. (1961). The Death and Life Cities of Great American Cities. New York: Penguin.

Jensen, Michael C, and William H Meckling. (1976). Theory of the Firm : Managerial Behavior, Agency Costs and Ownership Structure. Journal of Financial Economics 3 (4): 305-60.

Johnson, L. Jonathan, M. Catherine Daily, and E. Alan Ellstrand. (1996). Boards of Directors: A Review and Research Agenda. Journal of Management 22 (3): 409-38. https://doi.org/10.1177/014920639602200303.

Khan, Haroon ur Rashid, Waqas Bin Khidmat, Osama Al Hares, Naeem Muhammad, and Kashif Saleem. (2020). Corporate Governance Quality, Ownership Structure, Agency Costs and Firm Performance. Evidence from an Emerging Economy." Journal of Risk and Financial Management 13 (7): 154. https://doi.org/10.3390/jrfm13070154.

Kılıç, Merve, and Cemil Kuzey. (2016). The Effect of Board Gender Diversity on Firm Performance: Evidence from Turkey. Gender in Management 31 (7): 434-55. https://doi.org/10.1108/GM10-2015-0088.

Kusuma, Septian Yudha, Sudarman, and Dwi Astutik. (2018). Pengaruh Diversitas Gender Dewan Terhadap Kinerja Keuangan Pada Perbankan Yang Terdaftar Di BEl Periode 2014-2017. EQUILIBRIUM: Jurnal Ekonomi Syariah 6 (2): 253-69.

Lahlou, Ismail. (2018). Corporate Board of Directors Structure and Efficiency. Cham: Palgrave Macmillan.

Lai, Karen M.Y., Bin Srinidhi, Ferdinand A. Gul, and Judy Tsui. (2017). Board Gender Diversity, Auditor Fees and Auditor Choice. Contemporary Accounting Research 34 (3): 1681-1714.

Mahadeo, Jyoti D, Teerooven Soobaroyen, and Vanisha Oogarah Hanuman. (2012). Board 
Jurnal Personalia, Financial, Operasional,

Marketing dau Sistern Informasi

Performance. Volume 28 Nomor 1 Tahun 2021, 26-40

Composition and Financial Performance : Uncovering the Effects of Diversity in an Emerging Economy. Journal of Business Ethics 105 (3): 375-88. https://doi.org/10.1007/s10551-0110973-z.

Mahrani, Mayang, and Noorlailie Soewarno. (2018). The Effect of Good Corporate Governance Mechanism and Corporate Social Responsibility on Financial Performance with Earnings Management as Mediating Variable. Asian Journal of Accounting Research 3 (1): 41-60. https://doi.org/10.1108/ajar-06-2018-0008.

Miller, Toyah, and María del Carmen Triana. (2009). Demographic Diversity in the Boardroom: Mediators of the Board Diversity - Firm Performance Relationship. Journal of Management Studies 46 (5): 755-86.

Mishra, Ram Kumar, and Shital Jhunjhunwala. (2013). Diversity and the Effective Corporate Board. Academic Press.

Nahapiet, Janine, and Sumantra Ghoshal. (1998). Social Capital, Intellectual Capital, and the Organizational Advantage. Academy of Management Review 23 (2): 242-66. https://doi.org/10.2307/259373.

Nguyen, Anh Huu, Thu Minh Thi Vu, and Quynh Truc Thi Doan. (2020). Corporate Governance and Stock Price Synchronicity: Empirical Evidence From Vietnam. International Journal of Financial Studies 8 (2): 1-13. https://doi.org/10.3390/ijfs8020022.

Oever, Koen van den, and Bart Beerens. (2020). Does Task-Related Conflict Mediate The Board Gender Diversity-Organizational Performance Relationship? European Management Journal xxx (xxxx): 1-11. https://doi.org/10.1016/j.emj.2020.09.008.

Pearce, John A., and Shaker A. Zahra. (1992). Board Composition From A Strategic Contigency Perspective. Journal of Management Studies 29 (4): 411-38. https://doi.org/10.1111/j.1467-6486.1992.tb00672.x.

Pfeffer, Jeffrey. (1972). Size and Composition of Corporate Boards of Directors: The Organization and Its Size and Composition of Corporate Boards of Directors: The Organization and Its Environment. Administrative Science Quarterly $17 \quad(2)$ : 218-28. https://doi.org/10.2307/2393956.

Pfeffer, Jeffrey, and Gerald R. Salancik. (1978). The External Control of Organizations: A Resource Dependence Perspective. New York: Harper \& Row Publishers.

Phan, Thi Thu Hien, Lam Anh Lai, Thi Tam Le, Dung Manh Tran, and Dang Thuong Tran. (2020). The Impact of Audit Quality on Performance of Enterprises Listed on Hanoi Stock Exchange. Management Science Letters 10 (1): 217-24. https://doi.org/10.5267/j.msl.2019.8.001.

Pudjiastuti, Widanarni, and Aida Ainul Mardiyah. (2007). The Influence of Board Structure on Firm Performance. In SNA X, 1-43.

Ramadhani, Zhafarina Isti, and Desi Adhariani. (2015). Pengaruh Keberagaman Gender Terhadap Kinerja Keuangan Perusahaan Dan Efisiensi Investasi. In SNA XVII Lombok.

Reguera-Alvarado, Nuria, Pilar de Fuentes, and Joaquina Laffarga. (2017). Does Board Gender Diversity Influence Financial Performance ? Evidence from Spain. Journal of Business Ethics 
Jurnal Personalia, Financial, Operasional,

Marketing dam Sistem Informasi

Performance. Volume 28 Nomor 1 Tahun 2021, 26-40 141 (2): 337-50. https://doi.org/10.1007/s10551-015-2735-9.

Schweiger, D. M., W. R. Sandberg, and J. W. Ragan. (1986). Group Approaches for Improving Strategic Decision Making: A Comparative Analysis of Dialectical Inquiry, Devil's Advocacy, and Consensus. Academy of Management Journal 29 (1): 51-71. https://doi.org/10.2307/255859.

Singh, Jitendra V., Robert J. House, and David J. Tucker. (1986). Organizational Change and Organizational Mortality. Administrative Science Quarterly 31 (4): 587-611.

Steiner, Ivan Dale. (1972). Group Process and Productivity. New York: Academic press.

Swandayani, Desi Marilin, and Rohmawati Kusumaningtias. (2012). Pengaruh Inflasi, Suku Bunga, Nilai Tukar Valas Dan Jumlah Uang Beredar Terhadap Profitabilitas Pada Perbankan Syariah Di Indonesia Periode 2005-2009. Akrual 3 (2): 147-66.

Talavera, Oleksandr, Shuxing Yin, and Mao Zhang. (2018). Age Diversity, Directors' Personal Values, and Bank Performance. International Review of Financial Analysis 55 (January 2017): 60-79. https://doi.org/10.1016/j.irfa.2017.10.007.

Vermoesen, Veronique, Marc Deloof, and Armin Schwienbacher. (2020). Incentives Work: Performance-Related Remuneration of Directors before and during the Great Depression in Belgium. European Review of Economic History 24 (1): 192-218. https://doi.org/10.1093/ereh/hey022.

Wernerfelt, Birger. (1984). A Resource-Based View of the Firm. Strategic Management Journal 5 (171): 180. https://doi.org/10.1177/1056492611436225.

White, Harrison. (1961). Management Conflict and Sociometric Structure. American Journal of Sociology 67: 185-99. https://doi.org/10.1086/223084.

White, Harrison C. (1963). Cause and Effect in Social Mobility Tables. Behavioral Science 8: 1427. https://doi.org/10.1002/bs.3830080103.

Williamson, Oliver. (1984). Corporate Governance. The Yale Law Journal 93 (7): 1197-1230.

Zahra, Shaker A., and John A. Pearce. (1989). Boards of Directors and Corporate Financial Performance: A Review and Integrative Model. Journal of Management 15 (2): 291-334. https://doi.org/10.1177/014920638901500208. 